\title{
Pathogenicity and some structural features of Myxidium rhodei (Myxozoa: Myxosporea) from the kidney of the roach Rutilus rutilus
}

\author{
Iva Dyková ${ }^{1}$, Jiří Lom ${ }^{1}$ \& Ginka Grupcheva ${ }^{2}$ \\ 'Institute of Parasitology, Czechoslovak Academy of Sciences, 37005 České Budějovice, Czechoslovakia \\ ${ }^{2}$ Institute of Zoology, Bulgarian Academy of Sciences, Sofia, Bulgaria
}

\begin{abstract}
Two simultaneously occurring types of pathological change were observed in the kidney of Rutilus rutilus (L.) infected with Myxidium rhodei. Plasmodia in the renal corpuscles caused hypertrophy concurrent with atrophy of the surrounding renal parenchyma. Granulomatous reaction to these plasmodia occurred only when they were filled with spores. In contrast, plasmodia localized in the interstitium provoked a granulomatous inflammatory reaction at an early stage in their development. In heavy infections, there was severe damage to the kidney, involving a decrease in the number of glomeruli, atrophy of surrounding tissue, and granulomatous inflammatory changes in the interstitium. The ultrastructure of $M$. rhodei shows a general similarity to that of other polysporic plasmodia, except for 2 features: (1) generative cells often occur in pairs or groups of 3, penetrating one another with digitiform pseudopodia; (2) early pansporoblasts aggregate in groups formed by individuals clustering together across a thin sheet of plasmodial cytoplasm. The significance of these 2 features is not yet clear.
\end{abstract}

\section{INTRODUCTION}

Myxidium Bütschli 1882 is one of the most common myxosporean genera. In their review of 116 recorded species of Myxidium, Jayasri \& Hoffman (1982) pointed out that our knowledge of their pathogenicity is quite unsatisfactory. Copland's $(1981,1982,1983)$ work on histopathological changes caused by $M$. giardi in wild and cultured European eels is exceptional in this respect. Equally exceptional is the thorough study of taxonomy and morphology by Hine (1975). Most papers dealing with Myxidium are limited to new host records and records of infection sites for various species of the genus. Even a species as common as $M$. rhodei Léger 1905, known to occur in 32 host species (Shulman 1984), has never been assessed as a pathogen. In this paper we present data on the morphology and pathogenicity of $M$. rhodei.

\section{MATERIAL AND METHODS}

A total of 146 roaches Rutilus rutilus (L.) from various localities in Czechoslovakia and 125 from the Batak hydroelectric reservoir in Bulgaria were examined in 1980 to 1983 . Fresh scrapings from the gills and intesti- nal mucosa, tissue squashes from the liver, spleen and kidney, as well as gall bladder contents were examined in all instances. Histopathological examination of all these tissues was carried out on 211 specimens. The study of histopathological changes was based on 65 infected roaches: 23 from Czechoslovakia and 42 from Bulgaria.

Paraffin sections were stained with Giemsa and haematoxylin/eosin. Kidney lesions showed various stages of development, so that the course of their development could be traced. For TEM studies, infected renal corpuscles were fixed in $2 \%$ osmic acid in $0.1 \mathrm{M}$ cacodylate buffer, or double-fixed in $3 \%$ glutaraldehyde and $2 \%$ osmic acid, buffered as above. Sections of Epon-Araldite-embedded tissues were double-stained with magnesium uranyl acetate and lead citrate, and examined in a JEM 100B electron microscope at $80 \mathrm{kV}$.

\section{RESULTS}

\section{Identification of the parasite}

Myxidium rhodei Léger 1905 has spindle-shaped spores (Fig. 1) with about 21 to 23 longitudinal surface 


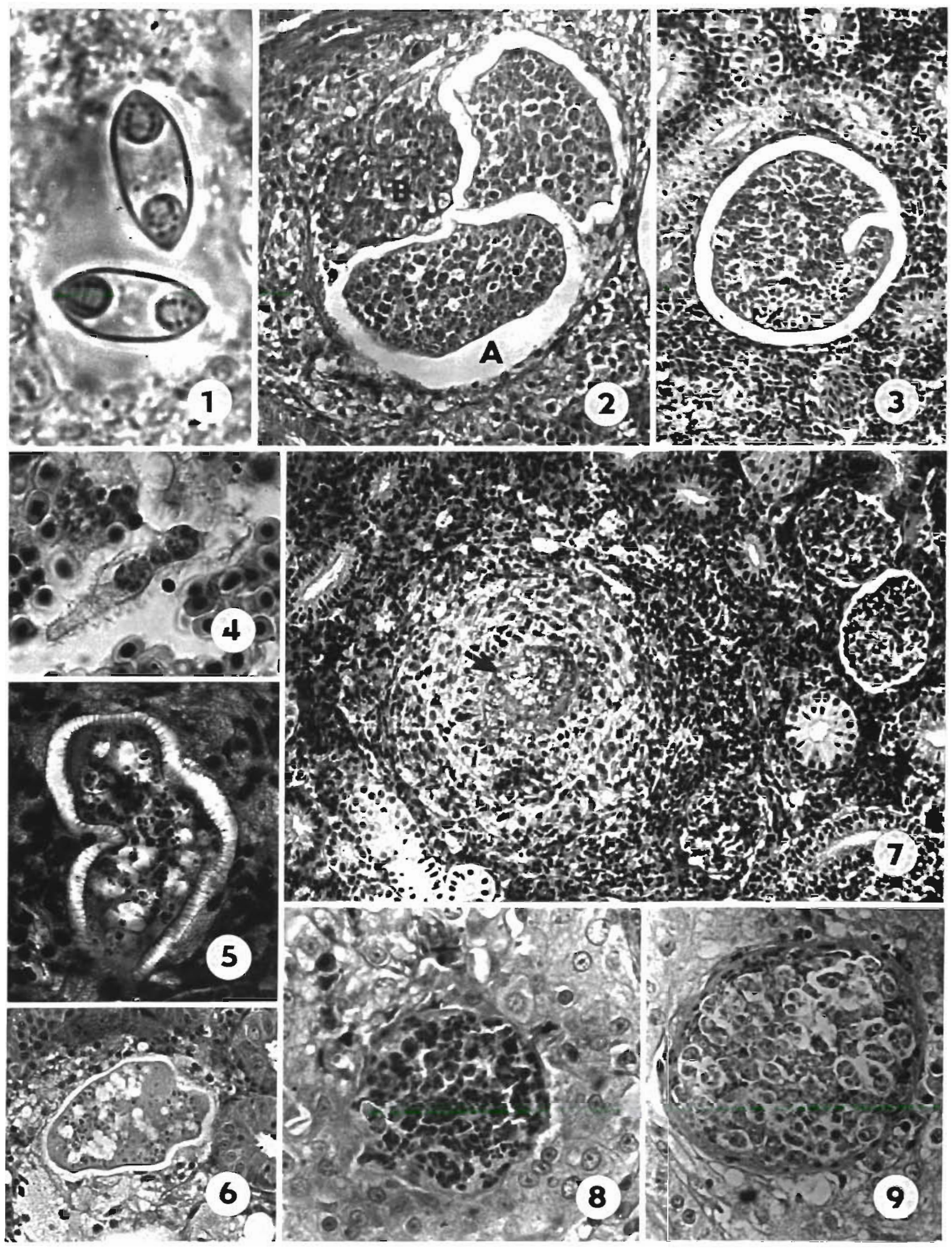

Fig. 1 to 9. Myxidium thodei in Rutilus rutilus. Fig. 1. Fresh spores of Myxidium rhodei, $\times 2550$. Fig. 2. Plasmodium of Myxidium rhodei developing outside capillaries in a hypertrophied renal corpuscle (A). B: atrophied glomerulus, HE $\times 255$. Fig. 3 .
Bowman's space of a renal corpuscle almost filled with a plasmodium, HE $\times 258$. Fig. 4 to 6 . Early developmental stages of interstitial forms with cell membrane thrown into conspicuous folds, $\mathrm{HE} \times 935,572$ and 340, respectively. Fig. 7 Inflammatory reaction provoked in the renal interstitium by an early stage of a plasmodium (arrow), HE $\times 270$. Fig. 8 . Inflammatory reaction in the renal interstitium. The plasmodium is surrounded by a wide zone of epithelioid cells, HE $\times 660$. Fig. 9. Granulomatous inflammatory reaction surrounding a trophozoite with maturing spores localized in the interstitium, $\mathrm{HE} \times 550$ 
ridges. Pooled size of the spores from 5 samples from Czechoslovakia ( $\mathrm{n}=30$ in each sample) was 10 to 15 $\times 4.6$ to $5.4 \mu \mathrm{m}$; polar capsules, usually with 5 coils of polar filaments, measured 2.8 to $3.6 \times 3.6$ to $4.4 \mu \mathrm{m}$, Polysporic plasmodia reached up to $0.5 \mathrm{~mm}$. M. rhode shares the same host species with 2 morphologically different species, $M$. macrocapsulare Auerbach 1910 and $M$. shulmani Chernova 1970 , as well as with the morphologically quite similar $M$. pfeifferi Auerbach 1908. The last-named species differs from $M$. rhodei mainly in its site of predilection, the gall bladder rather than the kidney. The differences, if any, between $M$. rhodei and $M$. pfeifferi warrant further investigation.

\section{Prevalence}

During the period of this study, the overall prevalence of Myxidium rhodei in Czechoslovak localities was $16 \%$. In the Batak reservoir, constructed in 1958, no roaches were recorded up to 1963 (Margaritov 1963). In 1978 and 1979, the prevalence of $M$. rhodei in that locality was $2.9 \%$ and $4.0 \%$, respectively. By 1980 it rose to $21.0 \%$ and by 1983 it reached $37.0 \%$. In about $25 \%$ of the infected Bulgarian roaches, $M$. rhodei occurred in the interstitium in addition to the glomeruli. No morbidity or mortality could be detected in natural habitats.

\section{Histopathology}

Plasmodia and spores of Myxidium rhodei were found only in the kidneys, most frequently in the Bowman's space of the renal corpuscles, but also in the renal interstitium. They were always larger in the former than in the latter location. Mature spores were only rarely free in the interstitium. A study of pathological changes in the 65 roaches examined showed that the nature and extent of pathological changes attributable to $M$. rhodei are determined primarily by the localization of plasmodia in the kidneys and, to a certain degree, by the stage of development of the plasmodia. Two simultaneously occurring types of pathological changes were found and examined histologically.

The first type of change occurred in the renal corpuscles and was characterized by hypertrophy, associated with atrophy of the surrounding renal parenchyma. Infected renal corpuscles were grossly enlarged. The extracapillary (Bowman's) space occupied by the plasmodia increased in size. The glomeruli were gradually compressed, so that separate segments of the capillary tuft could no longer been seen (Fig. 2). The walls of the capillaries were thick- ened by endothelial swelling and overlapped by the visceral sheet of Bowman's capsule with strikingly large podocytes. Sections at different levels showed that the glomeruli were not only displaced but that they also underwent gradual atrophy (Fig. 3). The parietal layer of Bowman's capsules was modified into a thin membrane, difficult to observe. The enlarging renal corpuscles, by exerting pressure, caused atrophy of the surrounding tissue, without any other marked changes. The resulting loss of functional parenchyma was, nevertheless, quite substantial in heavy infections. The renal corpuscles containing plasmodia with maturing spores were demarcated from the surrounding tissue by a very thin layer of mature connective tissue (Fig. 3). In more advanced infections, the renal corpuscles were replaced by masses of spores. The onset of granulomatous inflammatory reaction coincided with a loss in the stainability of the polar capsules. Large granulomas were formed, their peripheries consisting of lamellar layers of mature connective tissue; the central mass of spores was gradually pervaded by granulation tissue. These granulomas were subject to gradual involution.

The second type of change, a granulomatous inflammatory reaction, took place in the interstitium and was provoked by plasmodia located in that tissue. In contrast to the situation in the renal corpuscles, this reaction began at an early stage in the development of the plasmodia (Fig. 4 to 7). The local inflammatory reaction around them was characterized by the presence of a wide zone of epithelioid cells or foamy macrophages (Fig. 8 \& 9), including multinucleated giant cells of the foreign body type. Towards the periphery of the inflammatory focus, the fibroblasts, newly-formed capillaries, and lymphocytes became more numerous. In view of the very small number of plasmodia with mature spores in the interstitium, and considering the intensity of the inflammatory reaction to these plasmodia, it appears that many of them were destroyed prior to the development of mature spores.

\section{Electron microscopy}

Plasmodia containing developing and mature spores were observed in Bowman's spaces. The space between Bowman's capsules and the plasmodia appeared to be filled with finely flocculated material (Fig. 10). The plasmalemma of the parasite was thrown into ridges up to $1.3 \mu \mathrm{m}$ high (Fig. 11). Pinocytotic vesicles were rarely formed. The peripheral layer of cytoplasm was a rather lucent, homogenous substance; it contained fine vesicles and loose, free ribosomes but lacked fibrillar structures.

In addition to cell organelles such as mitochondria, 

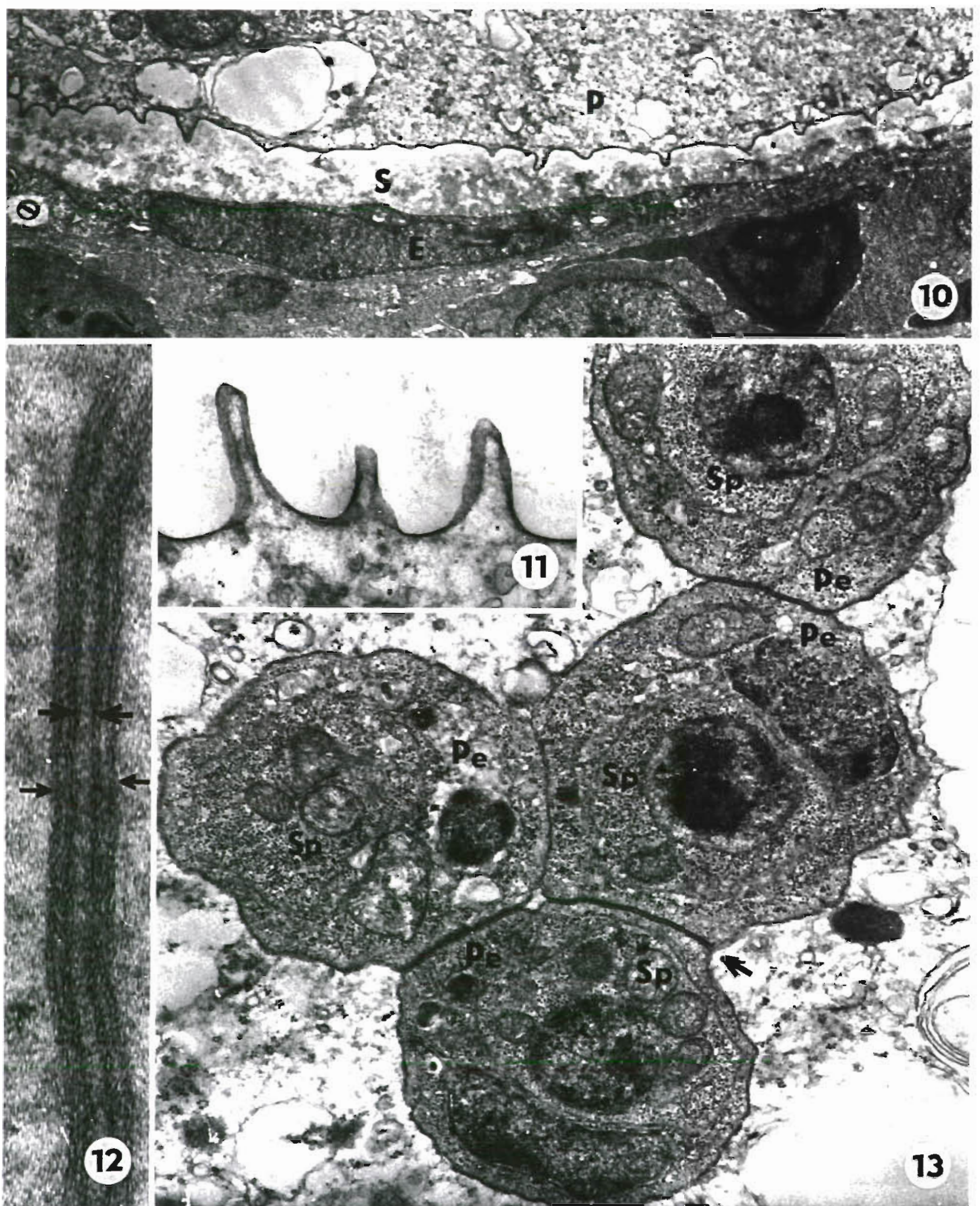

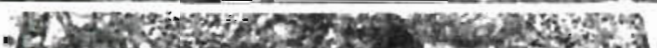
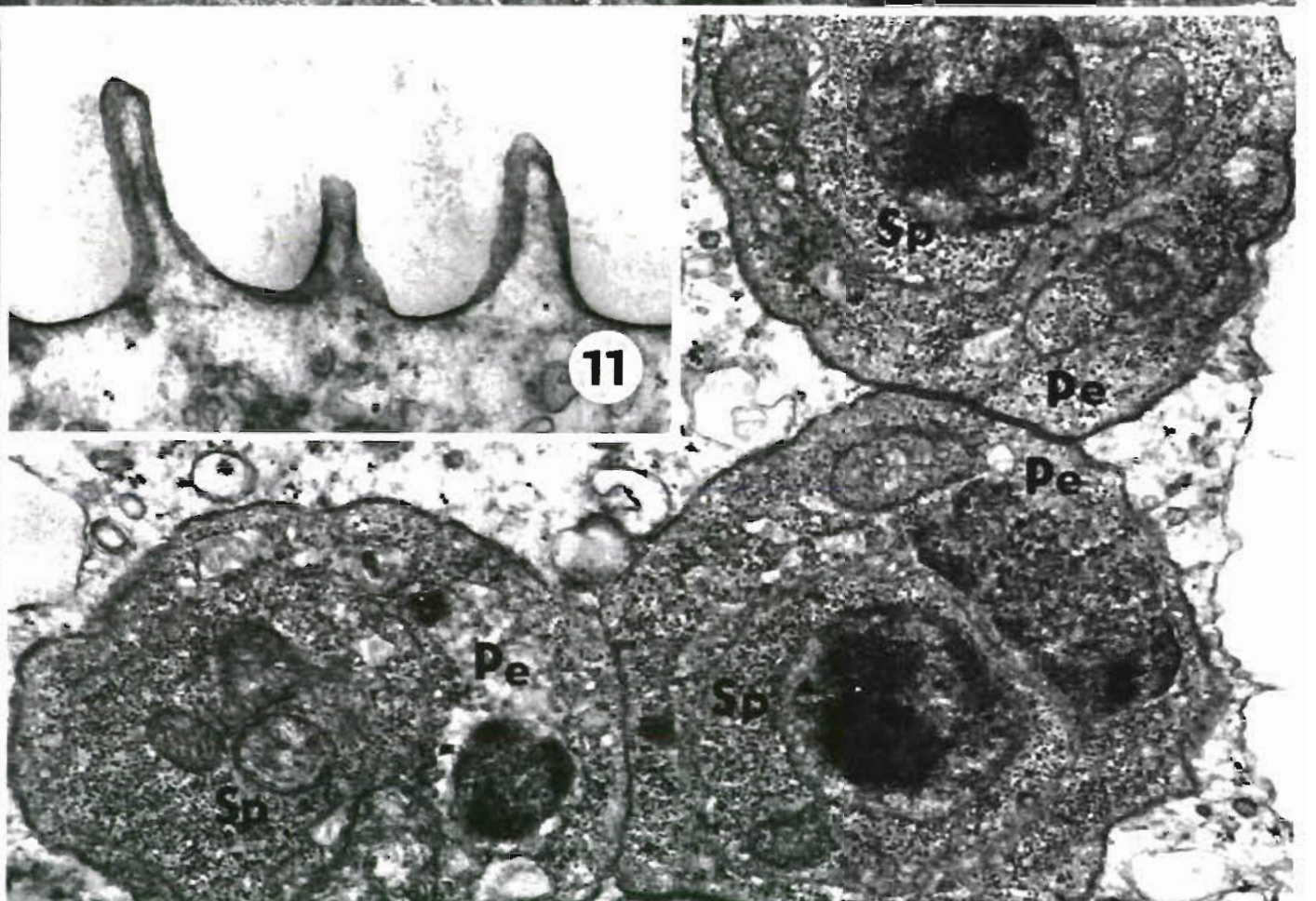
various vesicles, endoplasmic reticulum, and vacuoles, the plasmodial cytoplasm contained vegetative nuclei, generative cells, and various stages of sporogenesis. Most of the features of the parasite seemed to follow the pattern well known in the large polysporic plasmodia and, therefore, only some noteworthy structures will be mentioned.

The generative cells and pansporoblasts were covered with their own plasmalemma and, closely applied to it, another cell membrane, belonging to the mother plasmodium and forming a vacuole enclosing the generative cells. The latter seemed to be of one type, with cytoplasm filled with free ribosomes and some mitochondria. The nuclei had eccentric, prominent nucleoli. There were numerous, tube- or fingerlike, sometimes branched pseudopodia, up to $1.5 \mu \mathrm{m}$ long. Peculiar associations of generative cells could be observed: 2 cells, closely adhering to each other and piercing each other's cytoplasm with their tube-like pseudopodia. More often, 3 cells were grouped together in this manner. In such instances, one cell was sandwiched between 2 outer cells; the latter pierced the middle cell with their numerous pseudopodia, almost completely replacing the cytoplasm of the middle cell (Fig. 14\& 14b). All 3 cells lay within the common vacuolar membrane of the plasmodium (Fig. $14 \mathrm{a})$.

The earliest stage of sporogenesis observed was the cell doublet of a pericyte enveloping the inner sporogonic cell. The latter displayed the characteristic bundles of microtubules in its cytoplasm. These cell doublets often joined together to form clusters (Fig. 13) by adhering closely together along lines reminiscent of tight junctions.

High magnification revealed, however, that a thin layer (about $16 \mathrm{~nm}$ thick) of cytoplasm of the mother plasmodium was interposed between the cell doublets (Fig. 12). This meant that however close they may have

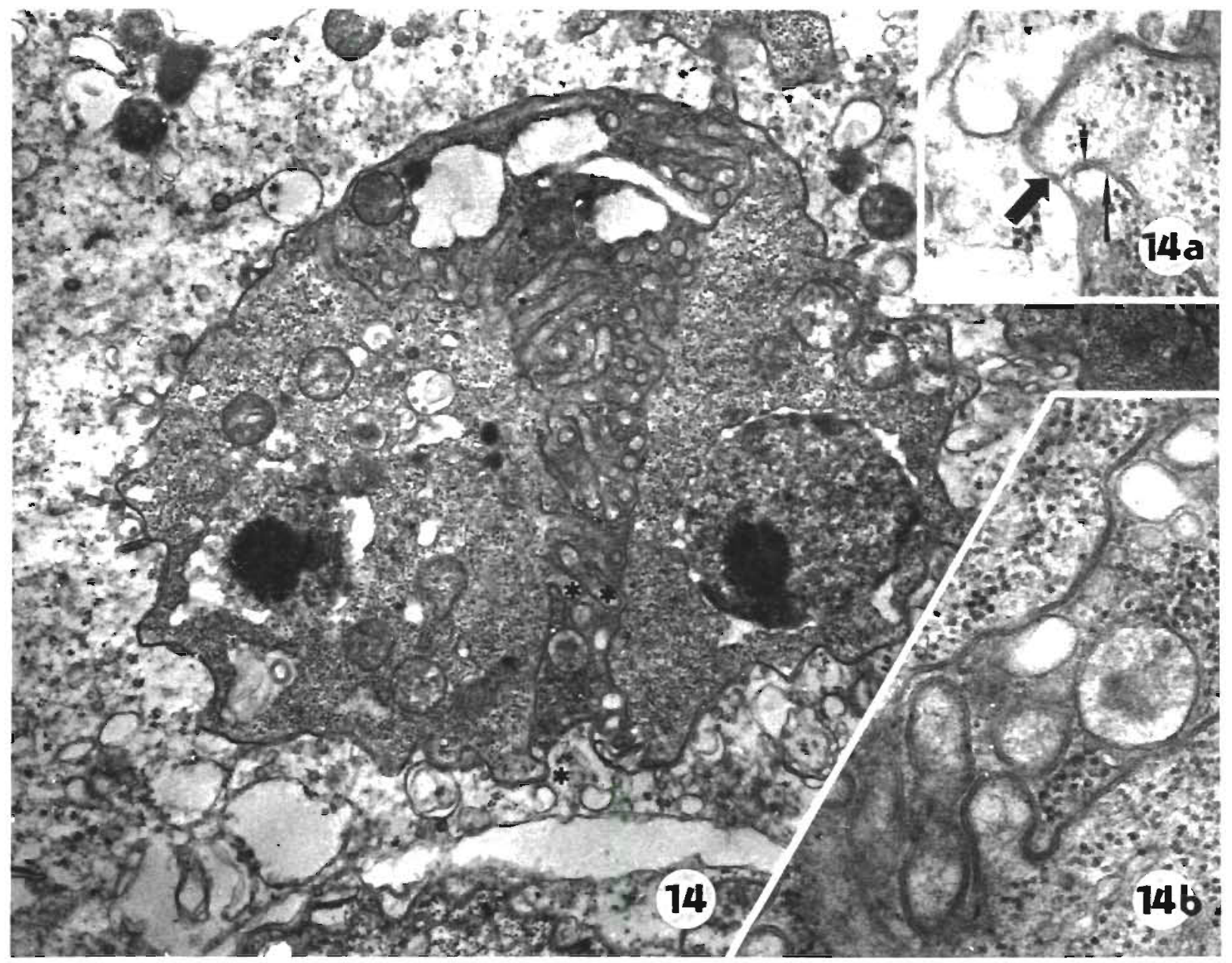

Fig. 14. Myxidium rhodei. A group of 3 generative cells. The cells at right and left pierce the centrally located cell with their tubular projections, $\times 23000$. Inset 14 a: detail of the area indicated by the asterisk in Fig. 14 ; small arrows point to cell membranes of generative cells; large arrow indicates common 'vaculolar' membrane of the plasmodium, $\times 61000$. Inset $14 \mathrm{~b}$ : area indicated by 2 asterisks in Fig. 14 
seemed to adhere to each other, they were, in fact, enclosed each in its own 'vacuolar' membrane. Pericytes enclosing 2 or 3 sporogonic cells of the future sporoblast could be seen still adhering together in this way. They separated, however, at a later stage and finished their sporogeny separately.

Pansporoblasts were disporic, i. e. each pericyte produced 2 (exceptionally one) spore. In the valvogenic cells, the developing ridges were subtended by a corset of microtubules. The rims of the valves seemed to be juxtaposed in the middle part of the spore, but they overlapped near the poles. Not all sporoblasts in a 'healthy' plasmodium produced spores. In some, development was abortive and the normal structure was not attained.

\section{DISCUSSION}

Our results indicate that Bowman's space of the renal corpuscles is the typical site of Myxidium rhodei. In this respect, this species resembles that identified by Miączyński (1956) in carp as M. pfeifferi, as well as Chloromyxum majori in salmonids (Yasutake \& Wood, 1957). We found plasmodia and spores only in the kidney. Kepr (in press) found trophozoites and spores of $M$. rhodei in the muscle tissue and liver of a single specimen of Rutilus rutilus but the heavy infection in this fish occurred in the kidney. Copland $(1981,1983)$ claimed that trophozoites of $M$. giardi are disseminated in eels via the vascular network. We could not corroborate it. Although we had in hand abundant material, collected at various seasons of the year, we failed to find initial stages of plasmodia in Bowman's space. (This failure might be attributable to the rapidity of the plasmodial development.) Incidentally, Copland $(1981,1983)$ also failed to observe the development of plasmodia of M. giardi in Bowman's spaces of kidneys in eels, the most common site of that parasite. All he recorded were masses of spores. Copland's (1981) conjecture that the coelozoic and histozoic trophozoites of $M$. giardi might differ in their ability to form spores appears to be borne out by our results. The intense inflammatory reaction provoked by the early stages of the interstitial plasmodia probably inhibited spore formation in this site and likely explains why mature spores were rarely found in the interstitial plasmodia. Trophozoites in Bowman's space did not induce such a reaction. Large spore masses, seemingly produced in the interstitium and bound by thin layers of connective tissue actually originated in the renal corpuscles, as shown in our sections. When the glomerular capillary tufts degenerated, the spores they contained seemed to be located in the interstitium.

Léger (1931) described the deposition of calcium salts in the mass of spores degenerating within thick capsules of connective tissue. The deposition was regarded as the final stage in the series of events occurring in the infected renal corpuscles. We did not observe this phenomenon.

The kidney damage can be severe in heavy infections due to the loss of functional glomeruli and to the atrophy, which affects the tissues surrounding the infected corpuscles. The development of plasmodia in the interstitium is associated with extensive inflammatory changes that alter the structure of the haematopoietic tissues in the interstitium. The nature and the severity of the changes provoked by Myxidium rhodei in roaches suggest that research on the pathogenicity of this myxosporean in other host species might be worthwhile.

The ultrastructure of Myxidium rhodei resembles that of large polysporic plasmodia, discussed by Lom et al. (1983) and Desser et al. (1983). Surface projections, which presumably increase the absorptive area, as well as conspicuous pseudopodia in generative cells, have also been observed in coelozoic species (e.g. Lom $\&$ de Puytorac 1965, Grassé \& Lavette 1978). However, the significance of doublets or triplets of generative cells, in which one cell pierces another with its tubelike pseudopodia, is not clear. It can hardly be regarded as a fusion process leading to pansporoblast formation. Neither can these cells be compared to lobocytes - distinctive scavenger cells within the plasmodia of Sphaeromyxa - which were presumed to ingest young sporoblasts (Grassé \& Lavette 1978). One might speculate that this is an unusual way in which generative cells feed by preying on their kin within the same mother plasmodium.

Cluster formation by early sporoblasts has not been hitherto observed in any other myxosporeans. Its significance eludes us. An investigation of its origin could throw some light on it.

These 2 examples provide additional evidence that the internal constituents of plasmodia may behave in different ways in various myxosporean groups. More information on other genera might bring us closer to the long sought for characters on which a more natural classification of these organisms might be based.

\section{LITERATURE CITED}

Copland, J. D. (1981). The occurrence and distribution of Myxidium giardi Cépède, 1906 in wild and cultured European eels, Anguilla anguilla L., in England. J. Fish Dis. 4; $231-242$

Copland, J. W. (1982). Myxosporidiosis caused by Myxidium giardi in cultured eels. In: Fowler, M. E. (ed.) Wildlife diseases of the Pacific basin and other countries. Wildlife Disease Association. USA, p. 175-177

Copland, J. W. (1983). The pathology of Myxidium giardi Cépède, 1906 infections in wild and cultured eels, Anguilla anguilla L. J. Fish Dis. 6: 451-460 
Desser, S., Molnar, K., Weller, I. (1983). Ultrastructure of sporogenesis of Thelohanellus nikolskii Akhmerov, 1955 (Myxozoa:Myxosporeal from the common carp, Cyprinus carpio.J. Parasit. 69: 504-518

Grassé, P. P., Lavette, A. (1978). La myxosporidie Sphaeromyxa sabrazesi et le nouvel embranchement des Myxozoaires (Myxozoa). Recherches sur l'état pluricellulaire primitif et considérations phylogénétiques. Ann. Sci. Nat. Zool. Paris 20: 193-285

Hine, P. M. (1975). Three new species of Myxidium (Protozoa: Myxosporidia) parasitic in Anguilla australis Richardson 1848 and $A$. dieffenbachi Gray, 1842 in New Zealand. J. R. Soc. N. Z. 5: 153-161

Jayasri, M., Hoffman, G. L. (1982). Review of Myxidium (Protozoa:Myxozoa:Myxosporea). Protozool. Abstr. 6: 61-91

Kepr, T. (1987). Myxidium rhodei Léger 1905 (Protozoa: Myxosporea) in the muscle and liver tissue of the roach, Rutilus rutilus L. Folia Parasit. 34: in press
Léger, L. (1931). Myxosporidies nouvelles ou peu connues du genre Myxidium chez les poissons d'eau douce. Trav. Lab Hydrobiol. Piscicult. Univ. Grenoble 22: 231-242

Lom, J., de Puytorac, P. (1965). Observations sur l'ultrastructure des trophozoites de myxosporidies. C. r. hebd. Séanc. Acad. Sci Paris 260: 2588-2590

Lom, J., Dykovấ, I., Lhotáková, S. (1983). Fine structure of Sphaerospora renicola Dyková and Lom, 1983, a myxosporean from karp kidney, and comments on the origin of pansporoblasts. Protistologica 18: 489--502

Miaczyński, T. (1956). Myxidium pfeifferi Auerbach and the origin of sporozoan cyst in fish kidney. Zool. Polon. 7: 121-126

Shulman, S. S. (1984) Parasitic Protozoa. In: Bauer, O. N. (ed.) Key to determination of the parasites of freshwater fish of the USSR, Vol. 1. Nauka, Leningrad, p. 426

Yasutake, W. T., Wood, E. M. (1957). Some Myxosporidia found in Pacific northwest salmonids. J. Parasit. 43: 633-637

Responsible Subject Editor: Dr. T. Evelyn; accepted for printing on January 14, 1987 